monarchie - Taliani, Poliaci, Rumuni, Čecho-Slováci a Juhoslovania sa zhodli na tom, že majú právo vytvorit’ si vlastné štáty a Rakúsko-Uhorsko pod nemeckou nadvládou je prekážkou na ceste za spoločným ciel'om. Rozhodli sa proti nemu preto spoločne bojovat'. Podl'a Leonciniho Rímsky pakt prekonal Londýnsku zmluvu z roku 1915, i ked’ sa počas mierových rokovaní ukázalo, že obidve strany predkladali etnicky neopodstatnené teritoriálne požiadavky na východnom pobreží Jadranu a v provincii Venezia Giulia. Dohoda medzi Talianmi a Juhoslovanmi patrila k ciel'om Milana Rastislava Štefánika, ktorému sa podarilo v mene Československej národnej rady 21. apríla 1918 podpísat's talianskou vládou zmluvu o utvorení a financovaní česko-slovenského vojska v Taliansku.

Monografiu dopíñajú publikované dokumenty z diplomatických archívov a talianskej tlače, ktoré ponúkajú bádatel'ovi možnost' hlbšie sa zoznámit' s problematikou talianskej politiky voči strednej Európe v druhej polovici 19. storočia, počas Vel'kej vojny a v nasledujúcom období s presahom až do súčasnosti.

Bohumila Ferenčuhová Historcký ústav SAV

BAUERKÄMPER, Arnd - ROSSOLIŃSKI-LIEBE, Grzegorz (Eds.). FASCISM WITHOUT BORDERS. Transnational Connections and Cooperation between Movements and Regimes in Europe from 1918 to 1945. New York, Oxford: Berghahn, 2017, 384 s. ISBN 9781785334689.

\title{
DOI: https://doi.org/10.31577/histcaso.2019.67.2.9
}

Historici a politológovia na poli fašistických štúdií dlhú dobu neboli schopní rozoznat' transnacionálny charakter fašizmu. Jednotlivé fašistické hnutia dlho študovali len v národných kontextoch a ako národné/nacionalistické fenomény. Žiadne hnutie však nemôže existovat' samostatne, izolovane, bez kontaktov, inšpirácií či transferov s vonkajším svetom. V posledných približne dvoch dekádach došlo, predovšetkým vd’aka „novej vlne“ $\left(\right.$ new wave) ${ }^{1} \mathrm{k}$ istej „renesancii“ a obnovenému záujmu o výskum fašizmu. Tentokrát sa však tento nový záujem netýka len západnej Európy - po páde železnej opony a návratu národných historiografií z chápadiel marxistických dogiem spät k slobodnému bádaniu sa výskum sústred’uje vo vel'kom i na fašistické hnutia v krajinách strednej, východnej a juhovýchodnej Európy. Vzbudilo to nový záujem o štúdium fašizmu v komparatívnej perspektíve a následne i nové zamyslenie sa nad existujúcimi definíciami fašizmu, ich fungovaním a možnou aplikáciou na široké spektrum predsa len špecifických hnutí tejto časti Európy. ${ }^{2}$ Neodlúčitel'ne je s tým spojené štúdium fašizmu ako transnacionálneho fenoménu.

1 GRIFFIN, Roger. Studying Fascism in a Postfascist Age. From New Consensus to New Wave? In Fascism. Journal of Comparative Fascist, Studies 1, 2012, s. 1-17. ISSN 2211-6257. 
Jednou z prvých prác tohto druhu vôbec, nepochybne s ambíciou byt' priekupníckou, je kniha Fascism without borders: Transnational Connections and Cooperation between Movements and Regimes in Europe, 1918-1945, ktorá vzišla z konferencie usporiadanej na pôde Freie Universität v Berlíne medzi 19. a 21. júnom 2014. Prácu editorsky zostavili práve organizátori tejto konferencie Arnd Bauerkämper a Grzegorz Rossoliński-Liebe, obaja pôsobiaci na berlínskej univerzite. V rozsiahlom úvode sa obaja editori zamýšl'ajú nad nedostatočnost'ou doterajšieho výskumu fašizmu v transnacionálnej perspektíve a naznačujú možnosti, akým smerom by sa „štúdiá fašizmu“ mohli uberat'. Týmito konštatovaniami si vlastne vystačia a čitatel' sa k žiadnej novej metodologickej pomôcke, či skutočne hlbokému zamysleniu nedopracuje. Pri svojom prehl'ade spolupráce hnutí v Európe sa navyše zameriavali až príliš na západnú Európu, konkrétne na taliansky fašizmus a nemecký nacizmus, a v neprimeranej miere tiež na v rámci Spojeného král'ovstva v podstate bezvýznamnú Britskú úniu fašistov (BUF). Stredná, východná a juhovýchodná Európa je úplne na okraji ich záujmu, pritom, ako som už zmienil, už takmer dekádu zaznievajú v západnej historiografii hlasy hovoriace o nevyhnutnosti komparatívneho výskumu, ktorý by zahŕňal i fašistické hnutia v tejto časti Európy. Slovenska sa dotknú v jednej vete, ale napríklad česká Národní obec fašistická či kolaborantská Vlajka nie sú zmienené vôbec. Neprimeraný a vlastne aj nezmyselný dôraz sa naopak dáva na režim Józefa Piłsudského, ktorý ale nemožno označit’ za fašistický.

Kniha má celkom trinást' kapitol, ktoré sa postupne venujú rôznym aspektom „,transnacionálneho" fašizmu i negatívnej reakcie naň - známej ako antifašizmus. Tematicky by sa dali rozdelit’ do 5 častí. Prvá, bezpochyby najvýznamnejšia a najpodnetnejšia čast’ práce má metodologický charakter. Pozostáva z dvoch štúdií Aristotela Kallisa a Matteo Pasettiho. Kallisova štúdia je najcennejšou čast’ou celej práce. Identifikoval v nej „,transnacionalitu“ fašizmu a vysvetlil, prečo nemôžeme fašizmus chápat', ani vysvetl'ovat' len v národnom kontexte. Fašizmus sa prejavil v rôznych hnutiach v Európe, pritom mal spoločný základ. Historici ho nikdy takto neštudovali, čo by sa podl'a Kallisa malo zmenit’. Autor tiež identifikoval základné charakteristiky toho, čo nazval „transnacionálny“ fašizmus - boli to podl'a neho násilie a antisemitizmus a zároveň snaha vytvorit' „,nového človeka“. Pasetti sa naopak pozrel na jednu špecifickú dimenziu fašistického „transnacionalizmu“ - korporativizmus. Vo svojom texte vysvetl'uje, ako si teoretický koncept ekonomického systému našiel vd'aka Mussolinimu cestu z Talianska do d'alších krajín po celej Európe i vo svete. Zároveň zdôrazňuje, že fašistický korporativizmus vo svojej úplnosti vlastne nikdy nefungoval a mnoho $\mathrm{z}$ toho, čo na Taliansku obdivovali fašisti po celej Európe vlastne neexistovalo a nebolo to nič iné než propaganda a „dymová clona“ zahal'ujúca fatálne zlyhania režimu v hospodárskej oblasti.

Druhá čast’ práce sa venuje propagande, vol'nému času a zobrazovaniu fašizmu. V tretej kapitole knihy sa doktorandka prof. Bauerkämpera Anna Lena Kocks pokúsila priniest' komparatívnu štúdiu vol'nočasových aktivít dvoch fašistických hnutí - talianskej Partito Nazionale Fascista (PNF) a britskej British Union of Fascists (BUF). Jej pokus neskončil úplne úspešne. I ked' priniesla nový zaujímavý pohl'ad na obe hnutia (nikto

a New Transnational Research Agenda. In East Central Europe, 2010, 37, s. 161-213. ISSN 1876-3308. 
ich doteraz neporovnával takýmto spôsobom), nedokázala dostatočne vyargumentovat', čo vlastne chcela svojou prácou ukázat' a jej záver, že taliansky fašizmus viedol diskurz fašistickej sebareprezentácie je l'ahko napadnutel'ný. Ak už niekto v 30. rokoch „,určoval trendy“, bola to Hitlerova NSDAP. Navyše, BUF si dokázala napriek svojej katastrofálnej finančnej situácii a podradnej úlohe $\mathrm{v}$ britskej politike (oproti talianskemu fašizmu, ktorý mal k dispozícii celú štátnu propagandistickú mašinériu) vytvorit’ pôsobivý vlastný image dynamického mladého vlasteneckého hnutia. $\mathrm{V}$ tomto zmysle nebola propaganda BUF neúspešná a rozhodne by som ju neoznačoval za menej sofistikovanú, než bola tá talianska (zvlášt' prihliadnuc $\mathrm{k}$ možnostiam, ktoré vyplývajú z odlišného postavenia marginálneho hnutia a režimu). Poukázanie na rozdiely medzi hnutiami (napr. v otázke žien a ich úloh) už je de facto len zopakovaním záverov staršej literatúry.

Naopak, omnoho pôsobivejšia je nasledujúca štúdia Gorana Miljana, absolventa Central European University, zaujímavá i pre slovenskú historiografiu. Miljan porovnával mládežnícke organizácie chorvátskeho hnutia Ustaša a Hlinkovej slovenskej l'udovej strany (HSL'S). Analyzoval pritom ich kontakty, výmenu ideí, myšlienok i medzištátnu kooperáciu. Obe hnutia samy seba vnímali ako hnutia za „oslobodenie“ $\mathrm{z}$ národnostného útlaku, ktorý mali pocitovat' v predchádzajúcich štátnych útvaroch a cítili sa duchovne príbuzné (najmä prostredníctvom katolicizmu). Miljan poukázal na spoločne organizované letné tábory v Chorvátsku i na Slovensku a ideologickú, jazykovú, religióznu a rasovú blízkost' oboch hnutí hl'adajúcich si svoje miesto v nacistickej novej Európe. Poslednou štúdiou tejto časti je text Cláudie Ninhos, ktorý sa zaoberal kontaktmi medzi nacistickým Nemeckom a Portugalskom v oblasti vedy, techniky, mládežníckych organizácií a podobne. Bližšie sa pozrela tiež na vplyv nemeckej propagandy (predovšetkým kultúrnej) na Portugalsko. Zaujímavému textu však chýba metodologická híbka a v podstate ide len o pozitivistický výpočet jednotlivých kontaktov.

Autori tretej časti sa zamerali na konflikty, náboženstvo a konkrétnych aktérov. Prvý text Grzegorza Rossoliński-Liebeho, jedného z editorov knihy, je znova o poznanie lepší od ostatných. Rossoliński-Liebe ukázal na príklade Rakúska, Rumunska a Ukrajiny, prečo sa nacisti vyhýbali spolupráci s domácimi fašistickými a radikálne pravicovými hnutiami. Na empirických príkladoch vel'mi správne ukázal, že nacistická politika bola do vel'kej miery podriadená geopolitickým záujmom (najmä vojnou so Sovietskym zväzom) a nacisti preferovali „pokoj v zázemi“ " pred radikálnymi revolučnými hnutiami, i ked’ ideologicky spriaznenými. Myšlienka to, samozrejme, nie je nijak inovatívna, avšak spôsob, akým s ňou Rossoliński-Liebe pracuje a využíva pri štúdiu primárnych prameňov je unikátny. Nadstavbou na jeho text by mohla tvorit’ väčšia komparatívna práca, ktorá by zahŕňala celý stredo- a východoeurópsky priestor (podobne napr. napriek opakovaným prosbám a žiadostiam nedali nacisti moc protektorátnej Vlajke, a to i napriek tomu, že de facto prevzala ich ideológiu a tiež zúrivý antisemitizmus).

Tretiu čast' uzatvárajú Raul Cârstocea a Marleen Rensen. Rensen priniesla pomerne zaujímavú sondu do života a myslenia francúzskeho intelektuála Roberta Brasillacha, ktorý konvertoval $\mathrm{k}$ fašizmu $\mathrm{v}$ druhej polovici 30 . rokov. Brasillach dokázal adaptovat' myšlienky nemeckého nacizmu na francúzske pomery a počas vojny s nacistami kolaboroval - stal sa šéfredaktorom pôvodne konzervatívneho, po novom fašistického denníka Je suis partout. Od roku 1942 požadoval obsadenie zbytku francúzskeho územia nemec- 
kým vojskom, popravu všetkých členov francúzskeho hnutia odporu a propagoval ideu nového Európskeho poriadku, kde by prím hrala nemecko-francúzska spolupráca. Po vojne ho za kolaboráciu odsúdili a obesili.

Podobne sa „transnacionálny“ charakter fašizmu pokúsil demonštrovat' na jednej osobe i Raul Cârstocea. Za predmet svojho výskumu si vybral jednu z vedúcich osobností rumunskej „Železnej gardy“ (Légie archanjela Michaela) Iona I. Moțu. Moța bol jeden z najhlasnejších podporovatel'ov Akčných výborov pre univerzálnost' Ríma (Comitati d'Azione per l'Universalita di Roma, CAUR), organizácie založenej Mussolinim začiatkom 30. rokov ako platformy pre vytvorenie medzinárodného fašistického hnutia. Moţa chcel medzinárodne spolupracovat' $\mathrm{v}$ boji proti spoločnému nepriatel'ovi - komunistom a Židom. Na konferencii v švajčiarskom Montreaux v decembri 1934 sa však stretol s pomerne chladnou reakciou ostatných zúčastnených hnutí.

Vo štvrtej časti sa čitatel' dozvie o rôznych konceptoch a víziách fašistov o novej Európe. Monica Fioravanzo sa vrátila k Mussoliniho CAUR a detailnejšie vysvetlila jeho zámer aj ideologickú a intelektuálnu spoluprácu, ktorá sa (aj) vd’aka tejto organizácii vytvorila. Zatial' čo jadrom vízií talianskych fašistov pre budúcu celoeurópsku spoluprácu a novú „fašistickú identitu“ bol Rím a kultúrna nadradenost' talianskeho fašizmu vychádzajúca z rímskych tradícií, nacisti zdôrazňovali rasu, eugeniku a dôležitost' ,, völkisch “ elementov v novej Európe pod nadvládou Nemecka - ako to vysvetl'uje v nasledujúcom texte Johannes Dafinger. Ani jeden z autorov nepriniesol prevratne nové koncepty či myšlienky, ktoré by sme nenašli už v staršej literatúre, dokázali však priniest' nový prístup a spôsob, akým na tieto už známe fakty nazerat'. Obzvlášt' Dafinger správne poukázal a vysvetlil proces ,prerodu“ viacerých nacistických ideológov od protieurópskeho zmýšl’ania k Európskym modelom.

Posledná piata čast' je venovaná „transnacionálnej“ spolupráci na opačnej strane politického spektra, a síce kontaktom a medzinárodnej spolupráci antifašistických hnutí. Všetci traja autori Kasper Braskén, Silvia Madotto a Francesco Di Palma poukázali na relatívne málo známy (predovšetkým v západnej historiografii) fenomén kooperácie antifašistov. Braskén sa venoval najmä komunistickému hnutiu. I ked' priniesol mnoho nových poznatkov, problémom jeho textu je nedostatočný dôraz na strednú a východnú Európu. Silvia Madotto sa venovala medzinárodnému antifašistickému hnutiu na univerzitách, čo je aj témou jej výskumu na doktoráte. V centre jej záujmu bola predovšetkým Padovská univerzita, kde pôsobil Silvio Trentin, taliansky partizán a univerzitný profesor, ktorý za svoje aktivity zaplatil v marci 1944 životom. Di Palma zas študoval kontakty medzi talianskym odbojovým hnutím Giustizia e Libertà a v tej dobe ilegálnou nemeckou sociálnou demokraciou (Sozialdemokratische Partei Deutschlands, SPD).

Knihu uzatvára druhý editor Arnd Bauerkämper, ktorý vo svojom texte naznačil možnosti d’alšieho výskumu $v$ tejto oblasti. Podobne ako pri úvodnej štúdii, ani teraz nešiel do híbky a viac-menej si vystačil s konštatovaním, že d’alší výskum v tejto oblasti je potrebný. Z nie celkom jasných dôvodov v knihe chýbajú príspevky prof. Rogera Griffina a prof. Constantina Iordachiho, ktorí na konferencii svoj výskum prezentovali (i ked' Griffin nie osobne, jeho prezentáciu prečítal prof. Bauerkämper). Ich príspevky mohli dat' publikácii chýbajúcu metodologickú hĺbku a širšiu perspektívu. To isté platí i pre prof. Wolfganga Wippermanna, ktorý sa konferencie taktiež zúčastnil, avšak je pra- 
vda, že vzhl'adom k veku už jeho hlas v „štúdiách fašizmu“ nie je tak silný, ako býval, a niekol'ko rokov nič prevratné nepublikoval.

Kniha Fascism without borders: Transnational Connections and Cooperation between Movements and Regimes in Europe, 1918-1945 tak nevyšla z tieňa „obyčajných“ konferenčných zborníkov, ktoré sa kvôli systému hodnotenia publikácií tvária ako kolektívne monografie. Napriek všetkej snahe editorov napísat’ „všeobjímajúci“ úvod, ktorý by dal knihe koncepciu, ide len o súhrn príspevkov rôznej kvality k náhodným témam, ktoré sa nejakým spôsobom dotýkajú problematiky medzinárodnej a cezhraničnej spolupráce fašistických či antifašistických hnutí. Napriek tomu túto publikáciu netreba zatracovat'. Ide o jednu z prvých prác v oblasti, na ktorú sa väčšina „,fašistológov“ momentálne začína sústred’ovat’ a ktorá bude bezpochyby „horúcou témou“ budúceho výskumu fašizmu. Priniesla niekol'ko zaujímavých a podnetných pohl'adov a svojím spôsobom naznačila smer, akým sa historiografia v tejto špecifickej oblasti môže d'alej vyvíjat'.

Jakub Drábik

Historický ústav SAV

\section{CHODĚJOVSKÝ, Jan (Ed.). PAŘÍŽ 1919. Mírová konference očima poradců československé a polské delegace. Praha: Nakladatelství Lidové noviny, 2017, 472 s. ISBN 9788074222702.}

\section{DOI: https://doi.org/10.31577/histcaso.2019.67.2.10}

Pre životné záujmy Československa a Pol’ska, dvoch nástupníckych štátov utvorených po rozpade habsburskej monarchie, predstavovala Parížska mierová konferencia v roku 1919 klúčový význam. Komplikovaný proces politickej rekonštrukcie strednej Európy pod taktovkou dohodových vel'mocí si vyžadoval, aby súčast'ou delegácií účastníckych štátov boli aj početní odborníci z rôznych vedných odborov. Archivár a historik Masarykovho ústavu a Archivu Akademie věd Českej republiky Jan Chodějovský obohatil pramenné spektrum k problematike účasti vedcov na parížskych rokovaniach o edíciu ego-dokumentov. Publikovanie denníka Adolfa Černého doplneného o korešpondenciu Václava Viléma Štecha a Kazimierza Nitscha má podl'a zámeru editora napomôct' pri skúmaní procesu formovania politických rozhodnutí a mechanizmu samotných rokovaní z pohl'adu účastníkov, ktorí pôsobili v zákulisí „vel'kých“ politických dejín. Pridanou hodnotou sú dobové svedectvá týkajúce sa bežného života odborných poradcov československej a pol'skej delegácie a spoločenskej atmosféry panujúcej v centre svetovej diplomacie. Na výbere textov, tvorbe medailónov a spracovaní poznámok k súboru listov pol'ského jazykovedca K. Nitscha s manželkou Anielou Gruszeckou sa podiel'ali pracovníci krakovskej inštitúcie Archiwum Nauki Polskiej Akademii Nauk i Polskiej Akademii Umiejętności Tomasz Skrzyński a Marcin Maciuk. Pol’ský jazykový variant obsahuje aj edičná poznámka a biografické portréty pôvodcov dokumentov.

V úvode edičnej poznámky J. Chodějovský oboznámil čitatel'ov s prehl'adom memoárovej literatúry, odborných prác, edícií dokumentov úradnej i osobnej povahy a osob- 